International Journal of Engineering \& Technology, 7 (4) (2018) 2835-2844
International Journal of Engineering \& Technology
SPC
Website: www.sciencepubco.com/index.php/IJET
doi: $10.14419 /$ ijet.v7it.17141
Research paper

\title{
Information system planning strategy on higher education institution based computer: a case study of a STIKOM yos sudarso purwokerto Indonesia
}

\author{
Adhi Wibowo $^{1}{ }^{*}$, Ariadi Nugroho ${ }^{1}$, Padosroha Marbun ${ }^{1}$, Diandra Chika Fransisca ${ }^{3}$ \\ ${ }^{1}$ Department of Information Technology, Universitas Bina Nusantra, Kebon Jeruk Raya Street No. 2, Kebon Jeruk, West Jakarta, 11530 , \\ Indonesia \\ ${ }^{2}$ Department of Information Technology, Sekolah Tinggi Ilmu Komputer Yos Sudarso Purwokerto, SMP 5 Karang Klesem Street, Pur- \\ wokerto, Central Java, 53144, Indonesia \\ *Corresponding author E-mail: adhi.wibowo28@gmail.com
}

\begin{abstract}
The study aims to describe planning strategies of information technology and information system on higher education based computer, especially College of Computer Science Yos Sudarso Purwokerto or "Sekolah Tinggi Ilmu Komputer Yos Sudarso Purwokerto" (STIKOM Yos Sudarso Purwokerto) Indonesia. The method was Enterprise Architecture Framework, in which each components of framework must utilities some analysis like SWOT analysis, IT Balanced Scorecard and Portfolio Application Framework. The result from Enterprise Architecture Framework documentation, can give a description to institution about development strategy of information system which is compatible with higher education institution vision and mission, as well as give input related to technology infrastructure condition and resource of institution. It is hoped that the blueprint can be implemented as a manual for developing institution.
\end{abstract}

Keywords: Enterprise Architecture; SWOT Analysis; IT Balanced Scorecard; Portfolio Application.

\section{Introduction}

Information Technology (IT) and Information System (IS) has become a primary need for every business sectors in Indonesia. The role of IT and IS has been proven in giving value added to every products and services of organization [1], in terms of manufacture [2], production [3], service [4], banking [5], government [6], as well education [7]. According to Hall, information system is a combination of formal procedure in which the data were classified, processed into information, and distributed to users [8].

Education is an important for nation to increase science and knowledge. Based on the data from Ministry Research, Technology and Higher Education which organized all higher education institutions registered in Indonesia, there are 4.504 legitimate higher education institutions including 3.136 Private Higher Education, 1.060 Islamic Higher Education, 186 State Higher Education and 122 Public Higher Education. The huge amount of higher education institutions in Indonesia shows the high competition, especially for Private Higher Education.

By the high competition, every higher education institution attempts to increase their value of services to win the competition. Consequently, the role of IT and IS becomes important to pay attention because IS usage concept is not only as a support but also as an enabler, in which its role is to make business processes easier and to make information technology a strong driver in creating new ideas which, at first, it is difficult to do without technology information support. A good information system will be useful for institution, so there is a need to determine information system strategy which is compatible with organization business strategy [9]. Information system development strategy requires analysis toward external and internal factor employing SWOT analysis. By the employment of SWOT analysis, the institution can identify the strengths, weaknesses, opportunities and threats internally and externally from company [10]. From the result of SWOT diagram, the institution can determine what kind of policy should be taken. STIKOM Yos Sudarso is one of private higher education institution in Purwokerto employing information technology as learning curriculum as well as business value improvement in its every service. This is done to make institution compete other institution not only in Banyumas regency but also beyond.

Regarding the underused information technology in STIKOM Yos Sudarso Purwokerto, especially information system development, it is hoped that this study can identify information about basic potential related to internal and external strategy factors which can be used for information system strategy development in STIKOM Yos Sudarso Purwokerto. Besides, documenting enterprise architecture related to information system is useful to make information system strategy planning in STIKOM Yos Sudarso which is appropriate to institution business need, as well as create information system application need plan in STIKOM Yos Sudarso to increase value of higher education in the future (Future Application Portfolio).

\section{Research method}

The study deployed Enterprise Architecture Framework method, containing discussion related to Goals \& Initiatives, Product \& Services, Data \& Information, System \& Application, Network and Infrastructure. The components in that framework applied in STIKOM Yos Sudarso Purwokerto were goals, process, standard 
and resource which can extensively line of business institution. Fig. 1

In the present architecture, STIKOM Yos Sudarso Purwokerto has EA components in each level of frameworks. It functions to create basic resource and activity, so the difference between the present and future activities reveals.

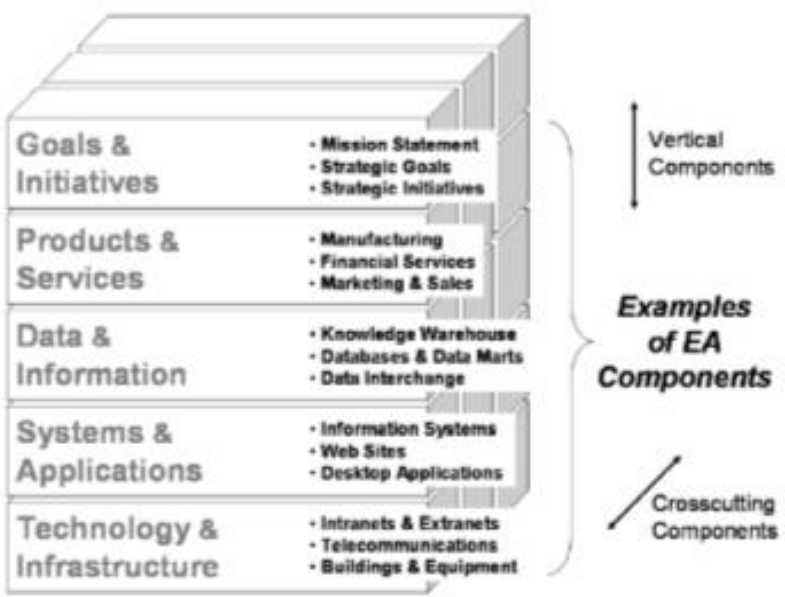

Fig. 1: Elements of Enterprise Architecture Framework [11].
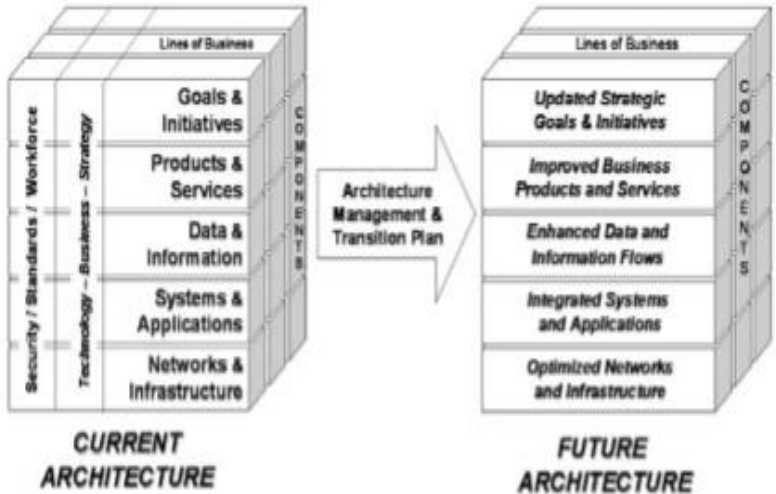

Fig. 2: Elements of EA Documentation [11].

This future architecture containing EA components belongs to STIKOM Yos Sudarso Purwokerto in which it is new or changes related to institution need to support new strategy initiative, operational or technology need.

By documenting Enterprise Architecture Framework, we need some analysis and methods applied, as the following explanations:

- SWOT analysis uses to analyze internal and external factor in terms of business process and information system, so the researcher can determine Goals \& Initiatives of this study. It is often used in environmental management as a diagnostic method to identify key factors affecting the success or failure of organization projects [12].

- IT Balanced Scorecard is used to measure information system performance in STIKOM Yos Sudarso Purwokerto based on 4 perspectives, including institution contribution, user orientation, operational improvement and future orientation. It aims to know if information technology has supported vision, mission and strategic goal of STIKOM Yos Sudarso Purwokerto as well as to document it into Goals \& Initiatives components of Enterprise Architecture Framework. Balanced Scorecard becomes an effective method to measure IT performance in organization, which supports organization in translating IT department strategy in specific purpose, action plan, and performance standard [13].

- Activity Diagram and Use Case Diagram are used to see the business process and information system development planning which is appropriate to user functional need.

- Portfolio Application Framework is used to interpret the present and used information system condition; higher edu- cation potential and application need to increase higher education value in the future (Future Application Portfolio); and description of SI application contribution of organization and future development.

- Enterprise Architecture Framework is used to identify scope of architecture which has to be documented and to make a relationship among architecture area in STIKOM Yos Sudarso Purwokerto.

\section{Results and discussion}

Based on the data obtained, the appropriate analysis is conducted to document enterprise aarchitecture created from combination of some analysis.

\subsection{SWOT analysis}

SWOT Analysis is used to identify basic potential information of internal and external factors which determines strategy used in strategy development [14]-[16]. It is done regularly to formulate STIKOM Yos Sudarso Purwokerto strategy. The analysis compares external factor (opportunities and threats) and internal factor (strengths and weaknesses). The SWOT Analysis of STIKOM Yos Sudarso Purwokerto is presented in Table 1. SWOT analysis of STIKOM Yos Sudarso Purwokerto is described in the followings.

a) Internal factor analysis: business strengths and weaknesses and IS/IT of STIKOM Yos Sudarso Purwokerto.

b) External factor analysis: business opportunity and threat and IS/IT of STIKOM Yos Sudarso Purwokerto.

Table 1: SWOT Analysis of STIKOM Yos Sudarso Purwokerto

\begin{tabular}{|c|c|c|c|}
\hline Code & Strengths & Code & Weaknesses \\
\hline S1 & $\begin{array}{l}\text { The availability of } \\
\text { computer and infor- } \\
\text { mation technology }\end{array}$ & W1 & $\begin{array}{l}\text { Has IT been used maximal- } \\
\text { ly? }\end{array}$ \\
\hline S2 & $\begin{array}{l}\text { The strong leadership } \\
\text { commitment is proved } \\
\text { by supporting effort of } \\
\text { institution development }\end{array}$ & W2 & $\begin{array}{l}\text { Lack of information system } \\
\text { development/ renewal }\end{array}$ \\
\hline S3 & $\begin{array}{l}\text { Leader support in ap- } \\
\text { plying technology }\end{array}$ & W3 & $\begin{array}{l}\text { The weakness of integration } \\
\text { in terms of function because } \\
\text { of ineffective control func- } \\
\text { tions in realizing vision and } \\
\text { mission of higher education. }\end{array}$ \\
\hline S4 & $\begin{array}{l}\text { Having the high } \\
\text { uniqueness related to } \\
\text { orientation in graduate } \\
\text { competition develop- } \\
\text { ment based humanities } \\
\text { value }\end{array}$ & W4 & $\begin{array}{l}\text { STIKOM Yos Sudarso is } \\
\text { still young }\end{array}$ \\
\hline Code & Opportunities & Code & Threats \\
\hline $\mathrm{O} 1$ & $\begin{array}{l}\text { The opening of CIT } \\
\text { development utilization } \\
\text { in supporting organiza- } \\
\text { tion management }\end{array}$ & $\mathrm{T} 1$ & $\begin{array}{l}\text { Unsimultaneous manage- } \\
\text { ment among divisions. }\end{array}$ \\
\hline $\mathrm{O} 2$ & $\begin{array}{l}\text { Development and pro- } \\
\text { gress of information } \\
\text { technology }\end{array}$ & $\mathrm{T} 2$ & $\begin{array}{l}\text { Lack of system manager } \\
\text { competition }\end{array}$ \\
\hline $\mathrm{O} 3$ & $\begin{array}{l}\text { There is a potential to } \\
\text { integrate data and in- } \\
\text { formation }\end{array}$ & T3 & $\begin{array}{l}\text { Competition among educa- } \\
\text { tion institutions in Infor- } \\
\text { mation Technology }\end{array}$ \\
\hline O4 & $\begin{array}{l}\text { The increase of society } \\
\text { awareness to give their } \\
\text { children education until } \\
\text { computer higher educa- } \\
\text { tion institution. }\end{array}$ & $\mathrm{T} 4$ & $\begin{array}{l}\text { Fast information technology } \\
\text { development }\end{array}$ \\
\hline
\end{tabular}

From the Table 1, EFAS and IFAS matrixes are formulated. EFAS matrix is formulated from out of STIKOM Yos Sudarso Purwokerto data as follows (see Table 2). Also, IFAS matrix are presented in Table 3. 


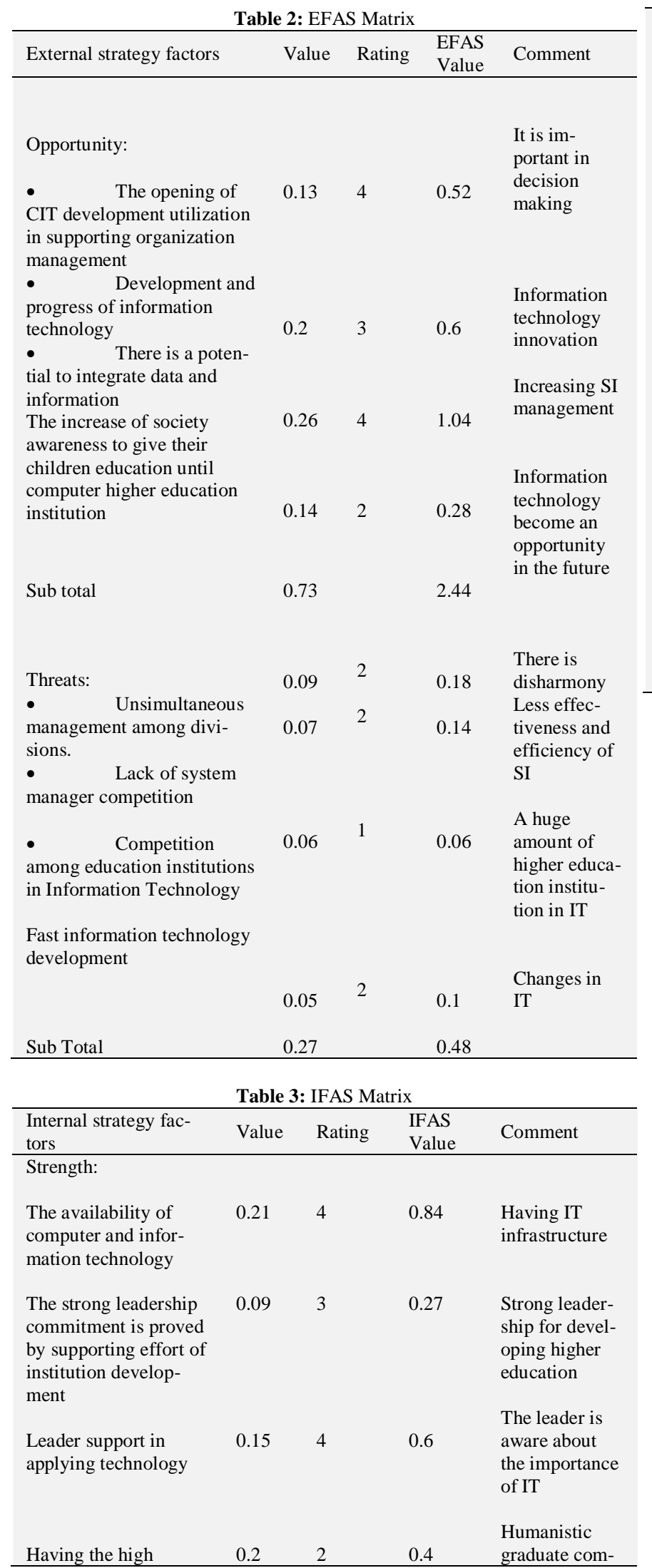

uniqueness related to

orientation in graduate

competition develop-

ment based humanities

value

Sub total

2.11

Weaknesses:

Has IT been used

maximally?

Lack of information

system development/

renewal

The weakness of inte-

gration in terms of

function because of

ineffective control

function in realizing

vision and mission of

higher education

STIKOM Yos Sudarso

is still young

$\begin{array}{llll}0.2 & 1 & 0.2 & \begin{array}{l}\text { It tends to be } \\ \text { manual }\end{array} \\ 0.06 & 1 & 0.06 & \begin{array}{l}\text { The present } \\ \text { information } \\ \text { system didn't } \\ \text { develop further }\end{array}\end{array}$

Less of IS

usage in help-

ing control

function

The small

amount of

higher educa-

Sub Total

0.36

tion graduate

After knowing IFAS and EFAS values, SWOT diagram is formulated to know STIKOM Yos Sudarso Purwokerto status.

To find it out is done by the difference between IFAS and EFAS

$\mathrm{X}$ Axes $($ internal $)=$ strengths - weaknesses $=2.11-0.39=1.72$

Y Axes $($ external $)=$ opportunities - threats $=2.44-0.48=1.96$

Fig. 3 shows the SWOT diagram.

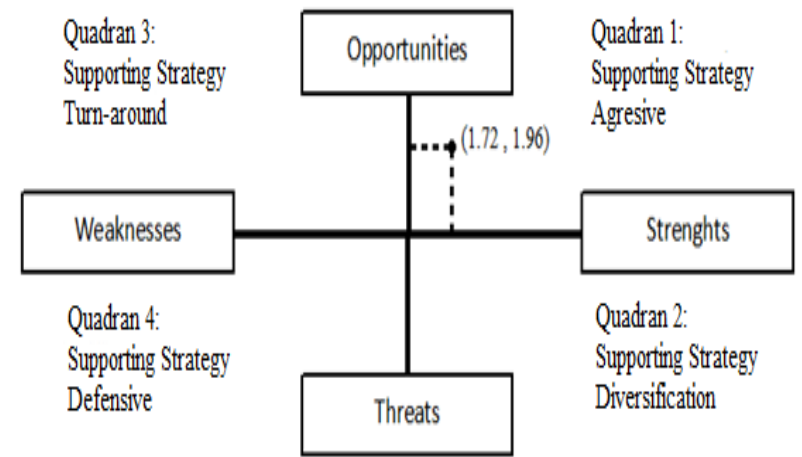

Fig. 3: SWOT Diagram.

\subsection{IT balanced scorecard}

IT Balanced Scorecard will be used to measure the performance of STIKOM Yos Sudarso Purwokerto information technology system with reference to 4 perspectives, including institution contribution, user orientation, operational improvement, and future orientation. It can be seen on Table 4. It aims to know if information technology sector has supported vision, mission and strategic goals of STIKOM Yos Sudarso Purwokerto. 


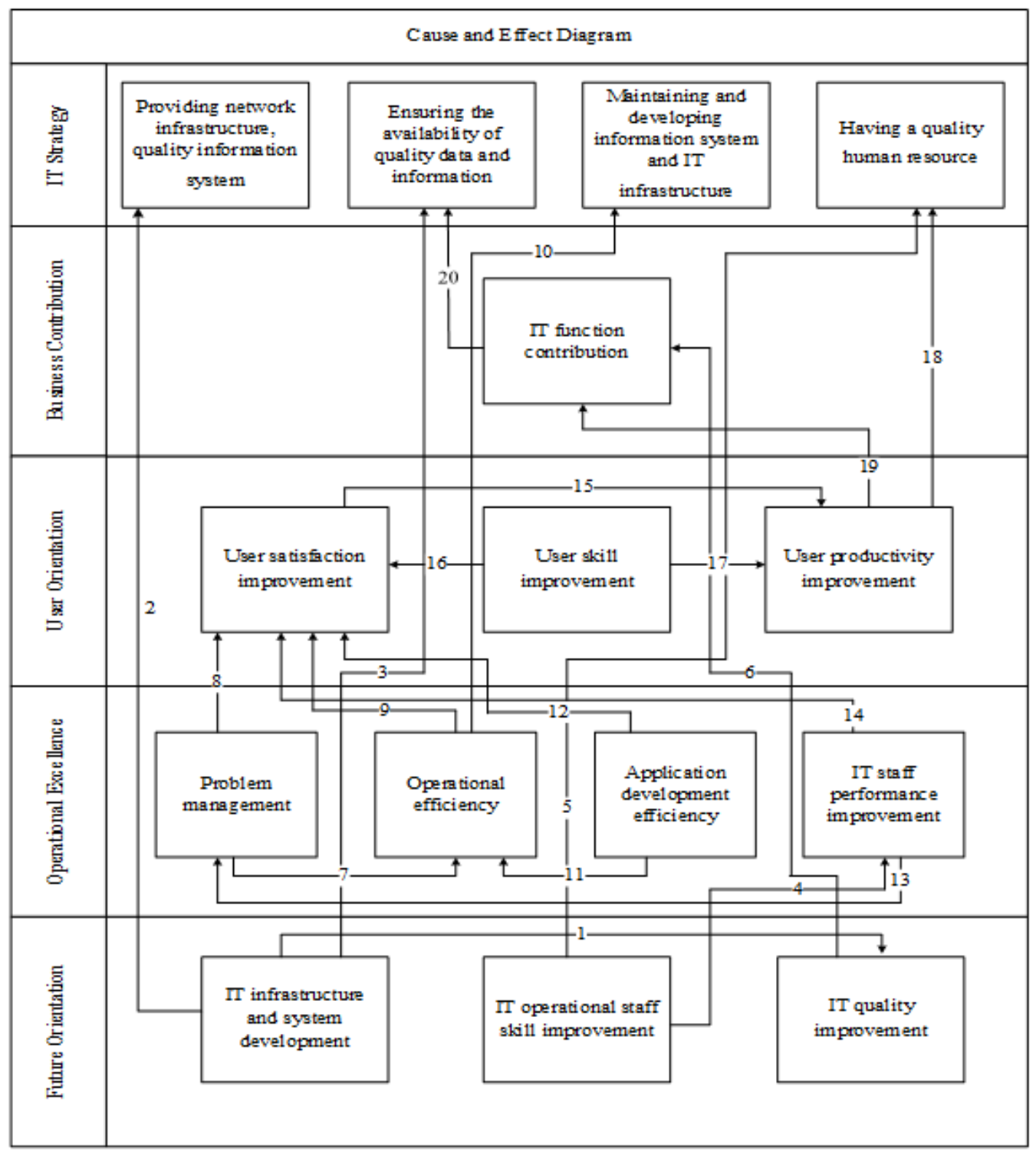

Fig. 4: Cause and Effect Diagram of IT Balance Scorecard.

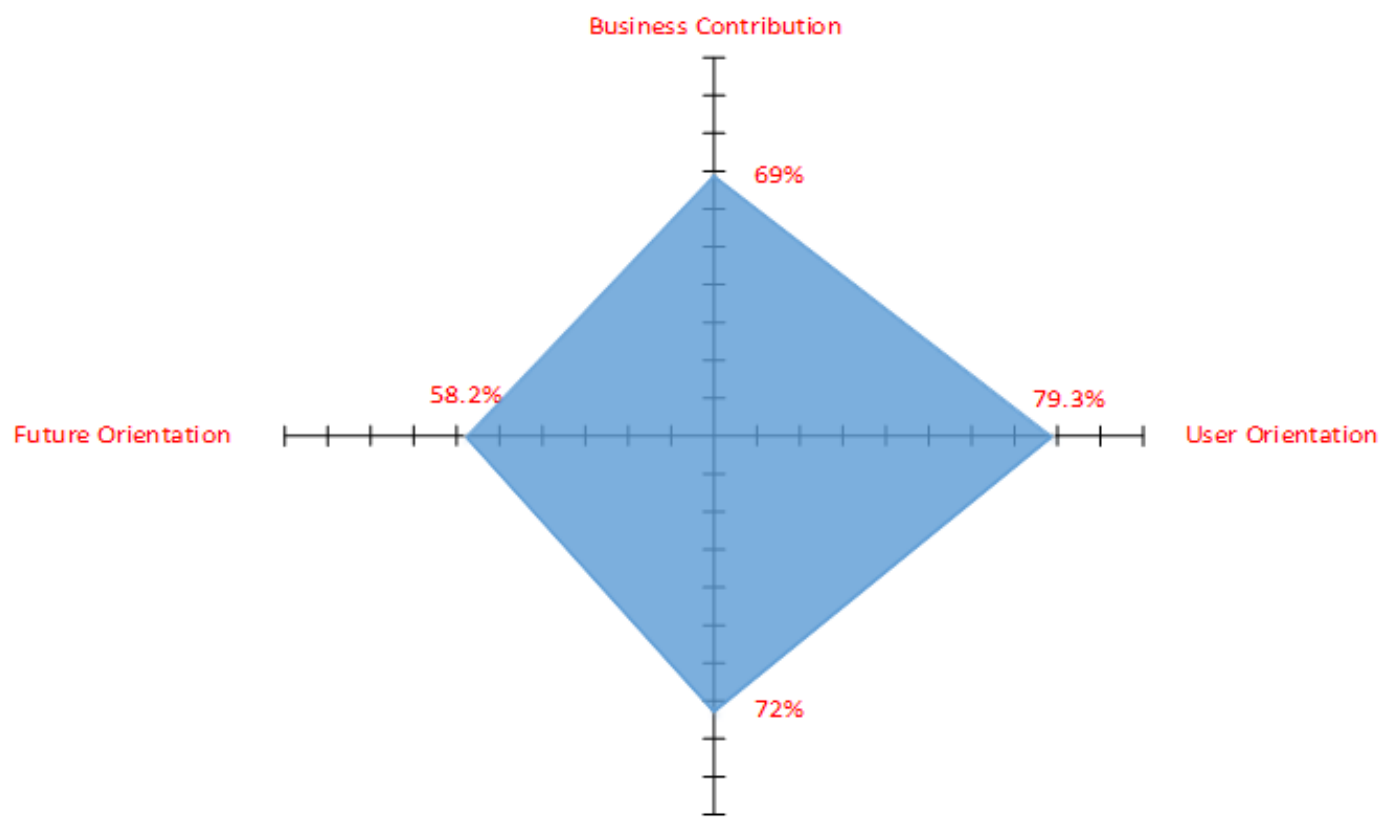

Operational Excellence

Fig. 5: IT Balanced Scorecard Measurement Results. 
1) IT System and infrastructure development $\rightarrow$ IT quality improvement. By developing IT system and infrastructure, IT quality automatically will also improve.

2) IT system and infrastructure development $\rightarrow$ Providing a quality network infrastructure, information system. The good IT system and infrastructure can fulfill the needs of human resource on network and information system in STIKOM Yos Sudarso Purwokerto.

3) IT system and infrastructure development $\rightarrow$ Ensuring the availability of quality data and information. By conducting IT system and information development, IT division will attempt to develop information system to fulfill the need of data and information through the good information system evolution.

4) IT operational staff skill improvement $\rightarrow$ IT staff performance improvement. By improving IT operational staff skill, it automatically will improve IT staff performance better. IT staff will be more competent in coping with all problems and will give better performance.

5) IT staff skill improvement $\rightarrow$ Having quality human resource in IT usage. Improving IT operational staff skill is one of institution need realizations in having quality human resource in IT usage.

6) IT quality improvement $\rightarrow$ IT function contribution. IT quality improvement will give significant contribution toward IT function.

7) Problem management $\rightarrow$ Operational efficiency. A good management problem will give efficiency in conducting daily operational.

8) Problem management $\rightarrow$ The increase of user satisfaction. A good problem management will also increase information system user satisfaction.

9) Operational efficiency $\rightarrow$ The increase of user satisfaction A definite operational efficiency will increase user satisfaction, because operational unit work becomes faster and easier.

10) Operational efficiency $\rightarrow$ maintaining and developing information system and IT infrastructure. A better operational efficiency will ease information system and IT infrastructure resource maintenance and development

11) Application development efficiency $\rightarrow$ Operational efficiency. By the good and efficient application development evolution, institution operational event will be faster, effective and efficient.

12) Application development efficiency $\rightarrow$ The increase of user satisfaction. The fast and good application development will help user in doing his/her work and will also increase information system user satisfaction.

13) IT staff performance improvement $\rightarrow$ Problem management A good IT staff performance will be able to solve problem and to improve problem management better.

14) IT staff performance improvement $\rightarrow$ The increase of user satisfaction. IT staff performance improvement as user in solving many problems can increase user satisfaction due to good application performance.

15) The increase of user satisfaction $\rightarrow$ User productivity improvement. The increase of user satisfaction will stimulate user productivity in solving many problems.

16) User skill improvement $\rightarrow$ The increase of user satisfaction User skill improvement will also increase user satisfaction, because the used application can cope with many problems.

17) User skill improvement $\rightarrow$ user productivity improvement By improving user skill, user productivity in solving problems will also improve.

18) User productivity improvement $\rightarrow$ Having quality human resource in IT usage. User productivity improvement is a realization of company strategy in having quality human resource, especially in using IT device.
19) User productivity improvement $\rightarrow$ IT function contribution. Improving user productivity will give a good IT function contribution in a useful IT application assembling.

20) IT function contribution $\rightarrow$ Ensuring the availability of quality data and information. The bigger IT function contribution will help in providing a better quality data and information.

Table 4: Formulating Strategic Goal of IS/IT

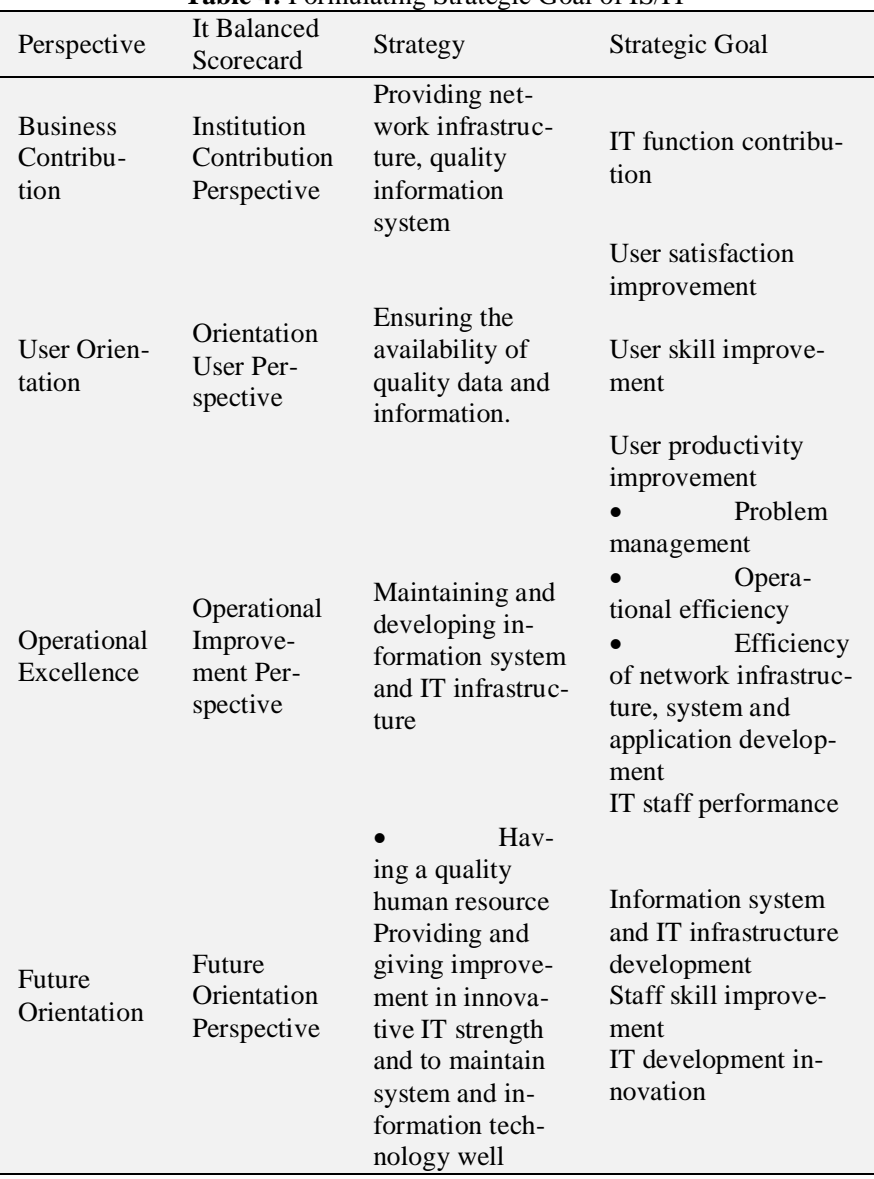

After creating cause and effect diagram (See Fig. 4), IT Balanced Scorecard is formulated based on strategic objective, measurement result (See Fig. 5) and its achievement (see Table 5).

IT balance scorecard measurement result based on four perspectives is shown in Fig. 5, in which its value measurement can be seen in Table 5. Besides, the measurement result considers value parameter in Table 6 . Therefore, it can be concluded that the measurement based business and future orientation is very bad, but the measurement based user orientation and excellent operation perspectives is bad as shown in Table 7. Consequently, a good strategy in information system development is required to improve organization performance in the future

Table 5: Strategic Objective and Its Achievement of IT Balanced Scorecard

\begin{tabular}{llll} 
Strategy Standard & $\begin{array}{l}\text { Strategic } \\
\text { Objective }\end{array}$ & $\begin{array}{l}\text { Measurement } \\
\text { Result }\end{array}$ & Achievement \\
\hline $\begin{array}{l}\text { Business Contribution } \\
\text { IT Function Contribution }\end{array}$ & & \\
$\begin{array}{l}\text { A.1 \% Process of } \\
\text { STIKOM Yos Sudar- } \\
\text { so business utilizing } \\
\text { information system } \\
\text { application }\end{array}$ & $100 \%$ & $50 \%$ & $50 \%$ \\
$\begin{array}{l}\text { A.2 \% Availability } \\
\text { network infrastruc- } \\
\text { ture, system, applica- } \\
\text { tion and data. }\end{array}$ & & \\
$\begin{array}{l}\text { Total } \\
\text { Average }\end{array}$ & & \\
User Orientation & $80 \%$ & $88 \%$ \\
\hline
\end{tabular}




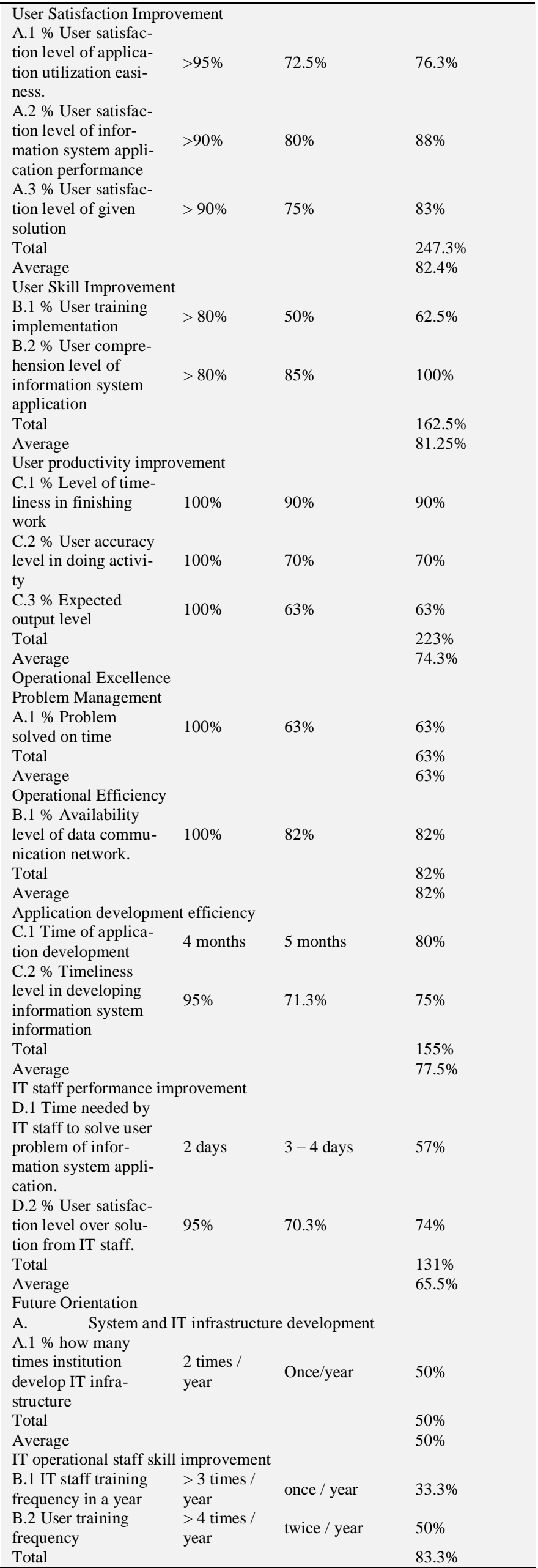

\begin{tabular}{|c|c|c|c|}
\hline Average & & & $41.65 \%$ \\
\hline IT quality improvem & & & \\
\hline C. $1 \%$ IT staff which & & & \\
\hline $\begin{array}{l}\text { is, at least, bachelor } \\
\text { degree }\end{array}$ & $100 \%$ & $100 \%$ & $100 \%$ \\
\hline $\begin{array}{l}\text { C. } 2 \% \text { IT support of } \\
\text { institution perfor- } \\
\text { mance }\end{array}$ & $100 \%$ & $66 \%$ & $66 \%$ \\
\hline Total & & & $166 \%$ \\
\hline Average & & & $83 \%$ \\
\hline
\end{tabular}

By evaluating the result of performance measurement, matrix assessment is created based on value category and then the result of IT performance measurement table is formulated, as follows (see Table 6):

Table 6: Assessment Matrix Based Value Category

\begin{tabular}{ll}
\hline Value & Value category \\
\hline $0 \%-70 \%$ & Very Bad \\
$71 \%-80 \%$ & Bad \\
$81 \%-90 \%$ & Good \\
$91 \%-100 \%$ & Very Good \\
\hline
\end{tabular}

The following is a result of IT performance measurement (see Table 7).

Table 7: The Result of IT Performance Measurement

\begin{tabular}{|c|c|c|c|}
\hline Perspective & Contribution & $\begin{array}{l}\text { Measurement } \\
\text { Result }\end{array}$ & Value \\
\hline \multirow{3}{*}{$\begin{array}{l}\text { Business } \\
\text { Contribution } \\
\text { Average }\end{array}$} & $\begin{array}{l}\text { IT function contri- } \\
\text { bution }\end{array}$ & $69 \%$ & Very Bad \\
\hline & & $69 \%$ & Very Bad \\
\hline & $\begin{array}{l}\text { User satisfaction } \\
\text { improvement }\end{array}$ & $82.4 \%$ & Good \\
\hline \multirow[t]{2}{*}{$\begin{array}{l}\text { User Orienta- } \\
\text { tion }\end{array}$} & $\begin{array}{l}\text { User skill im- } \\
\text { provement }\end{array}$ & $81.25 \%$ & Good \\
\hline & $\begin{array}{l}\text { User productivity } \\
\text { Improvement }\end{array}$ & $74.3 \%$ & $\mathrm{Bad}$ \\
\hline \multirow[t]{3}{*}{ Average } & & $79.3 \%$ & $\mathrm{Bad}$ \\
\hline & $\begin{array}{l}\text { Problem manage- } \\
\text { ment }\end{array}$ & $63 \%$ & Very Bad \\
\hline & $\begin{array}{l}\text { Operational effi- } \\
\text { ciency }\end{array}$ & $82 \%$ & Good \\
\hline \multirow{2}{*}{$\begin{array}{l}\text { Operational } \\
\text { Excellence }\end{array}$} & $\begin{array}{l}\text { Application devel- } \\
\text { opment efficiency }\end{array}$ & $77.5 \%$ & $\mathrm{Bad}$ \\
\hline & $\begin{array}{l}\text { IT staff perfor- } \\
\text { mance Improve- } \\
\text { ment }\end{array}$ & $65.5 \%$ & Very Bad \\
\hline \multirow[t]{2}{*}{ Average } & & $72 \%$ & Bad \\
\hline & $\begin{array}{l}\text { System and IT } \\
\text { infrastructure } \\
\text { Improvement }\end{array}$ & $50 \%$ & Very Bad \\
\hline \multirow[t]{2}{*}{$\begin{array}{l}\text { Future Orien- } \\
\text { tation }\end{array}$} & $\begin{array}{l}\text { IT operational } \\
\text { staff skill im- } \\
\text { provement }\end{array}$ & $41.65 \%$ & Very Bad \\
\hline & $\begin{array}{l}\text { IT quality im- } \\
\text { provement }\end{array}$ & $83 \%$ & Good \\
\hline Average & & $58.2 \%$ & Very Bad \\
\hline
\end{tabular}

The following Table 8 is the brief summary of performance measurement result:

Table 8: Summary of Performance Measurement Result

\begin{tabular}{ll}
\hline Perspective & Measurement Result \\
\hline Business Contribution & $69 \%$ \\
User Orientation & $79.3 \%$ \\
Operational Excellence & $72 \%$ \\
Future Orientation & $58.2 \%$ \\
Average & $69.625 \%$ \\
\hline
\end{tabular}




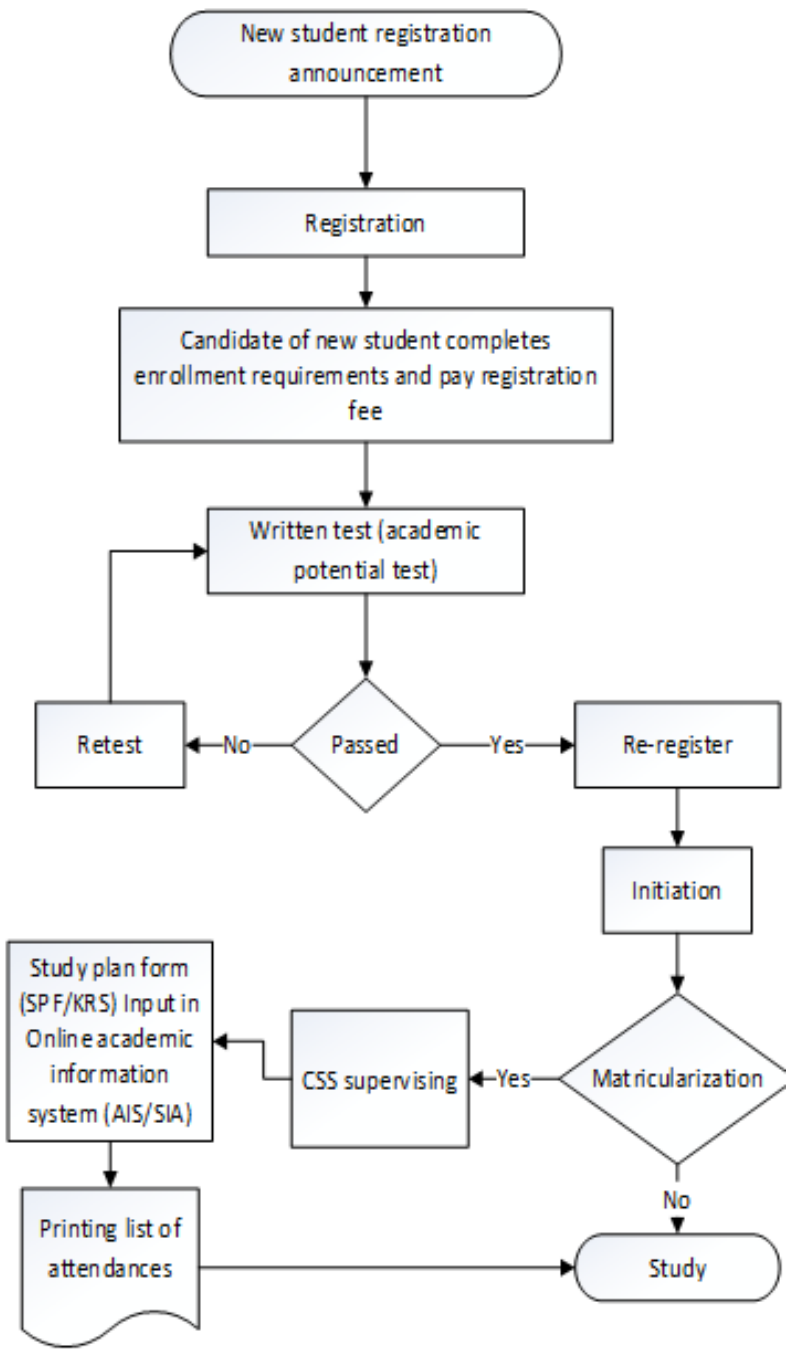

Fig. 6: New Student Enrollment Process Diagram.

\subsection{Enterprise architecture}

This documentation of analysis result and recommendation which has been proposed to STIKOM Yos Sudarso Purwokerto uses Scott A. Bernard framework, its components are explained in the followings:

\subsubsection{Goals and initiatives}

Goal and Initiatives is explained through SWOT analysis and IT Balanced Scorecard.

\subsubsection{Product and services}

Products and services of STIKOM Yos Sudarso are shown in New Student Enrollment Process Diagram (see Fig. 6). Developing New Student Enrollment Information System expectedly gives value added related to the easiness of accessing information about enrollment. The diagram is shown Fig. 6.

\subsubsection{Data and information}

Documentation related to institution data and information is summarized based on data accessibility with internet usage in each institution business process. Data accessibility with internet usage is shown in the Table 9.
Table 9: Data Accessibility with Internet Usage

\begin{tabular}{|c|c|c|c|c|}
\hline \multirow[b]{2}{*}{ Data } & \multicolumn{3}{|c|}{ Data Management System } & \multirow[b]{2}{*}{$\begin{array}{l}\text { Using } \\
\text { computer } \\
\text { with broad } \\
\text { network } \\
\text { (Internet) }\end{array}$} \\
\hline & Manually` & $\begin{array}{l}\text { Using } \\
\text { computer } \\
\text { without } \\
\text { network }\end{array}$ & $\begin{array}{l}\text { Using } \\
\text { computer } \\
\text { with local } \\
\text { network } \\
\text { (Intranet) }\end{array}$ & \\
\hline Student & & & & $\sqrt{ }$ \\
\hline Payment & & & & $\sqrt{ }$ \\
\hline Study Plan & & & & \\
\hline Form & & & & $\sqrt{ }$ \\
\hline (SPF) & & & & \\
\hline Schedule & & & & $\sqrt{ }$ \\
\hline Grade & & & & $\sqrt{ }$ \\
\hline Academic & & & & $\sqrt{ }$ \\
\hline Transcript & & & & $\sqrt{ }$ \\
\hline Graduate & & & & $\sqrt{ }$ \\
\hline Lecturer & & & & $\sqrt{ }$ \\
\hline Staff & & & & $\sqrt{ }$ \\
\hline Support & & & & $\sqrt{ }$ \\
\hline Staff & & & & $\sqrt{ }$ \\
\hline Finance & & & & $\sqrt{ }$ \\
\hline Inventory & & & & $\sqrt{ }$ \\
\hline Library & & & & $\sqrt{ }$ \\
\hline Total & $\mathrm{N}_{\mathrm{A}}=$ & $\mathrm{N}_{\mathrm{B}}=$ & $\mathrm{N}_{\mathrm{C}}=$ & $N_{D}=13$ \\
\hline
\end{tabular}

\subsubsection{System and applications}

System and applications is describes in a framework portfolio application. It aims to give description about information system application which is good for institution and to give benefits in the future. It is explained in the followings.

Some recommendations of information system strategy is created based on the previous application including:

- New Student Enrollment Information System

- Staff and Lecturer Recruitment Information System

- Cooperation Information System

- Lecturer and Student Academic Information System

- Payment Administration Information System

- Online Attendance System

- Subject Schedule Information System

Table 10: Portfolio of STIKOM Yos Sudarso Application

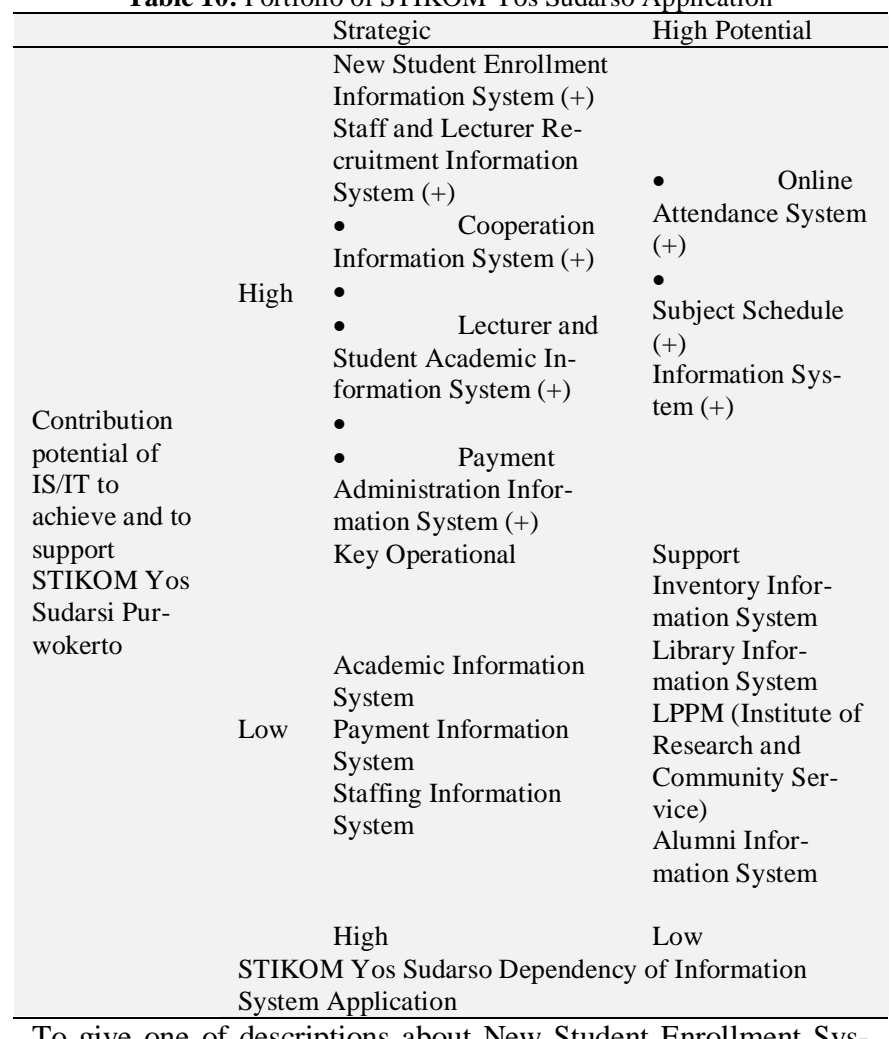

To give one of descriptions about New Student Enrollment System development, the researcher uses Use Case Diagram created 
after User Need Analysis. The diagrams are shown in Fig. 7 and Fig. 8 .

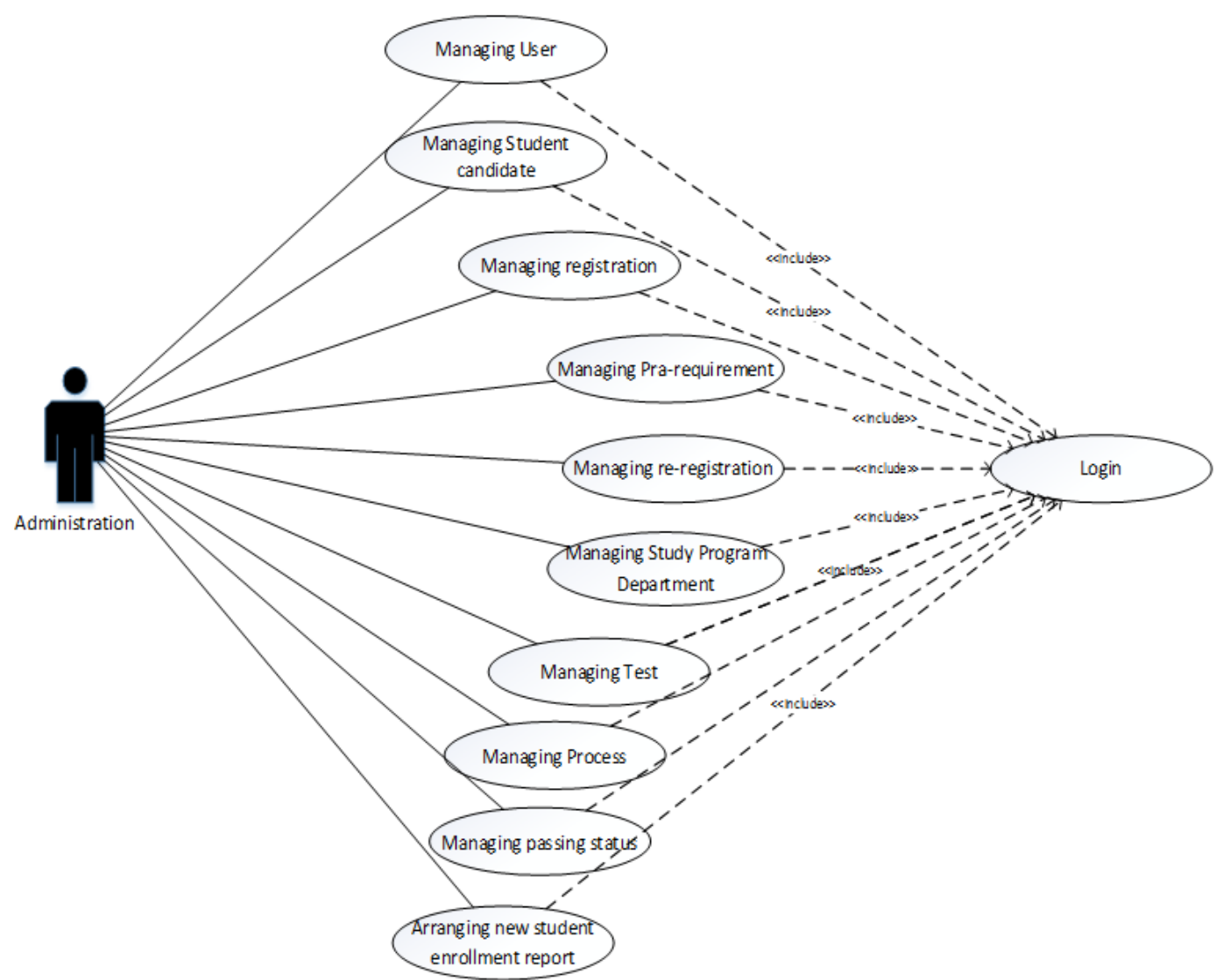

Fig. 7: Use Case of New Student Enrollment Information System Diagram for Administrator.

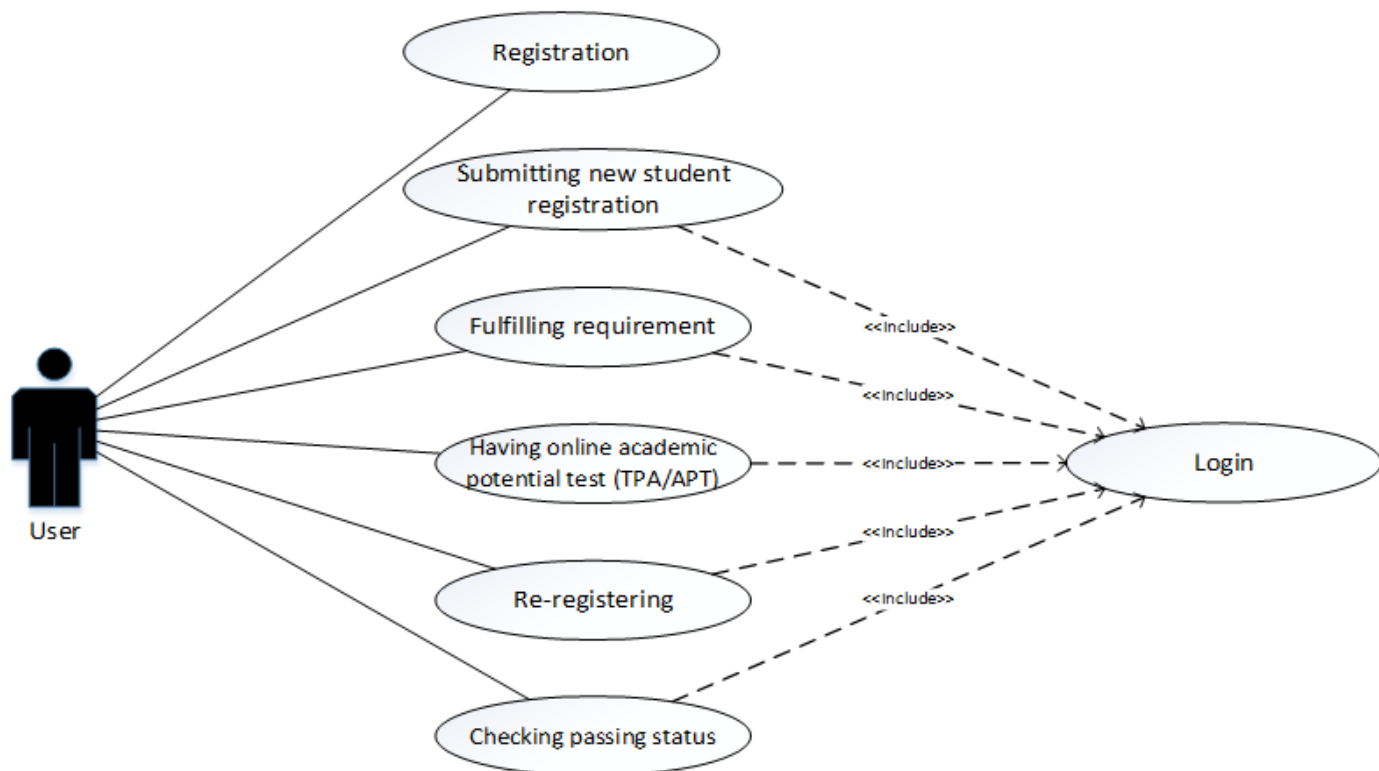

Fig. 8: Use Case of New Student Enrollment Information System Diagram for User.

\subsubsection{Network and Infrastructure}

STIKOM Yos Sudarso has internal network with using star typology and ISP, so each node can access internet service providing by institution. It also has three-story building, and in the terrace there are gazeboes used by student to keep in touch one another. By using microtic router, network classes are divided appropriately in each class. It is also added in each laboratory, lecturer, General Administration Office, Academic Administration and Finance Office and chairperson rooms. Hotspot is also available in gazeboes. Some access point is provided in each story so internet usage is available in each story. Internet network scheme in di STIKOM Yos Sudarso Purwokerto is shown in Fig. 9. 


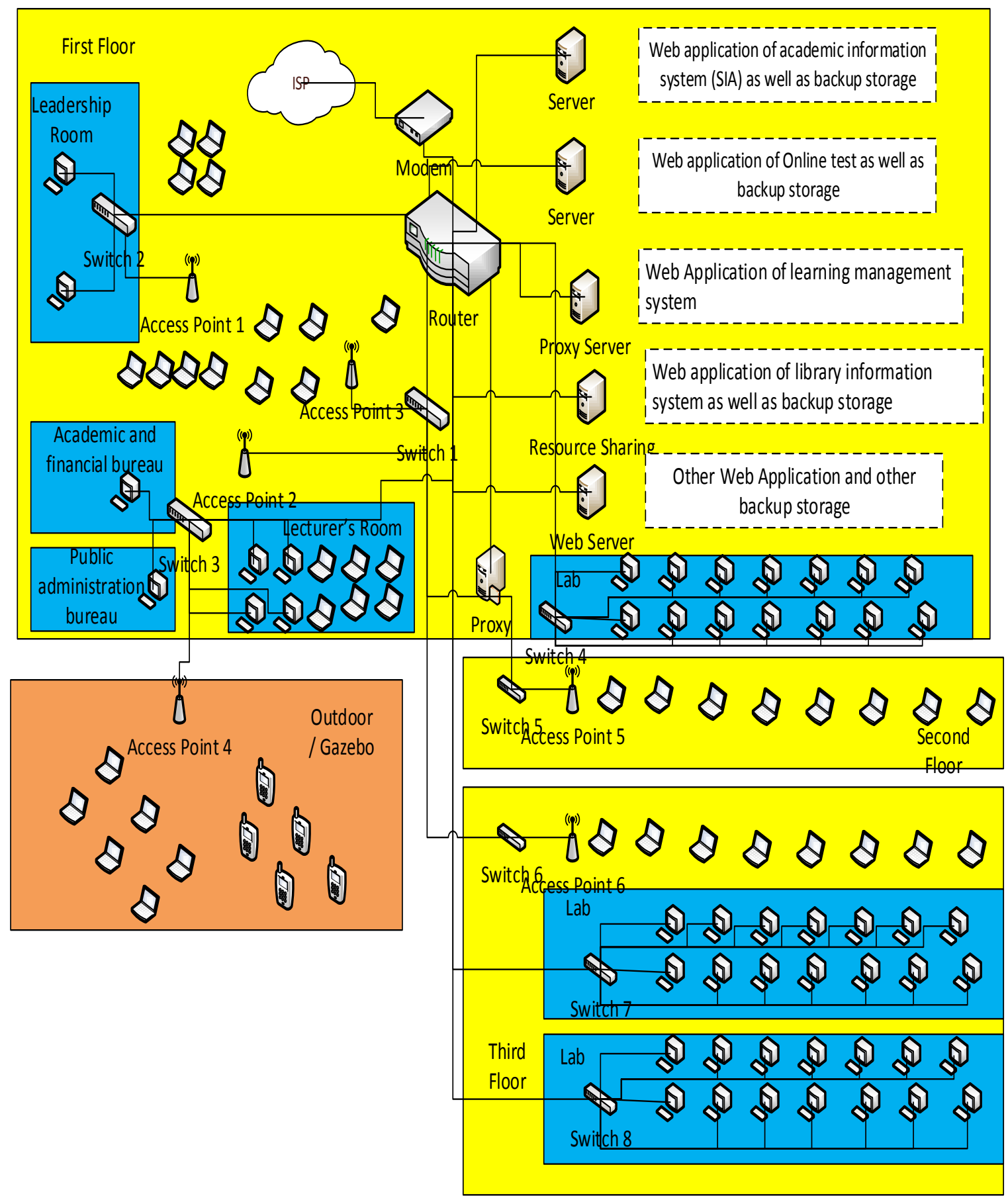

Fig. 9: Internet Network of STIKOM Yos Sudarso.

\section{Conclusion}

Based on analysis result, it is concluded that internal and external factor analysis result with reference to SWOT Analysis can give a description about strengths, weaknesses, opportunities and threats which has to be faced by STIKOM Yos Sudarso in terms of business and information technology. Besides, IT Balanced Scorecard analysis result can give indication about higher education condition in accordance to 4 perspectives including institution contribution, user orientation, operational improvement and future orientation. Furthermore, documentation result of Enterprise Architecture created by researcher is expectedly able to give a clear description related to information technology infrastructure and information technology resource of STIKOM Yos Sudarso Purwokerto, as well as further information system development strategy for STIKOM Yos Sudarso Purwokerto.

\section{References}

[1] Komala AR. 'Cause and effect of accounting information system: A study in national Zakat management organization". Journal of Administrative and Business Studies. Vol. 3, No. 2, (2017), pp. 69-76.

[2] Theorin A, Bengtsson K, Provost J, Lieder M, Johnsson C, Lundholm $\mathrm{T}$ and Lennartson B. "An event-driven manufacturing information system architecture for Industry 4.0". International Journal of Production Research, Vol. 55, No. 5, (2017), pp. 1297 1311. https://doi.org/10.1080/00207543.2016.1201604.

[3] Dewan S and Min CK. "The substitution of information technology for other factors of production: A firm level analysis". Management science, Vol. 43, No. 12, (1997), pp. 1660-1675. https://doi.org/10.1287/mnsc.43.12.1660.

[4] Berkley B J and Gupta A. "Improving service quality with information technology". International journal of information management, Vol. 14, No. 2, (1994), 109-121. https://doi.org/10.1016/0268-4012(94)90030-2. 
[5] Mocetti S, Pagnini M and Sette E. "Information technology and banking organization". Journal of Financial Services Research, Vol 51, No. 3, (2017), pp. 313-338. https://doi.org/10.1007/s10693-0160244-3.

[6] Landsbergen JD and Wolken JG. "Realizing the promise: Government information systems and the fourth generation of information technology". Public administration review, Vol. 61, No. 2, (2001), pp. 206-220. https://doi.org/10.1111/0033-3352.00023.

[7] Kadiyala $M$ and Crynes BL. "A review of literature on effectiveness of use of information technology in education". Journal of engineering education, Vol. 89, No. 2, (2000), pp. 177-189. https://doi.org/10.1002/j.2168-9830.2000.tb00512.x.

[8] Hall JA. Accounting information systems, Thomson Learning, (2001).

[9] Ward J and Peppard J. Strategic Planning for Information System. John Wiley \& Sons, (2002).

[10] Abid H. C, Ahmad S and Khalil A. "Strenght, Weaknesses, Opportunities and Threats: An Analysis of University of the Punjab". Bulletin of Education and Research, Vol. 38, No. 2 pp. 229-247.

[11] Bernar S. Enterprise Architecture, 3rd edition. San Bernardio, CA: Author House, (2012).

[12] Masozera MK, Alavalapati JR, Jacobson SK and Shrestha RK. "Assessing the suitability of community-based management for the Nyungwe Forest Reserve, Rwanda". Forest Policy and Economics, Vol. 8, No. 2, (2006), pp. 206-216. https://doi.org/10.1016/j.forpol.2004.08.001.

[13] Addo T, Chow CW and Haddad KM. Development of an IT Balanced Scorecard. Journal of International Technology and Information Management, Vol. 13, No. 4, (2004), pp. 219-238.

[14] Wheelen TL and Hunger JD. Strategic management and business policy: Toward global sustainability, Pearson Prentice Hall, (2012).

[15] Leiber T, Stensaker B and Harvey LC. "Bridging theory and practice of impact evaluation of quality management in higher education institutions: a SWOT analysis". European Journal of Higher Education, Vol. 8, No. 3, (2018), pp. 1-15. https://doi.org/10.1080/21568235.2018.1474782.

[16] Yuksel I. "An Integrated approach with group decision-making for strategy selection in SWOT analysis". International Journal of Research in Buisness and Social Science, Vol. 2, No. 11, (2012), pp. 134-161. 